\title{
Climate regime of Asian glaciers revealed by GAMDAM glacier inventory
}

\author{
A. Sakai ${ }^{1}$, T. Nuimura ${ }^{1, *}$, K. Fujita ${ }^{1}$, S. Takenaka ${ }^{1}$, H. Nagai ${ }^{1, * *}$, and D. Lamsal ${ }^{1}$ \\ ${ }^{1}$ Graduate School of Environmental Studies, Nagoya University, Nagoya, Japan \\ *now at: Chiba Institute of Science, Chiba, Japan \\ ** now at: Earth Observation Research Center, Japan Aerospace Exploration Agency, Tsukuba, Japan
}

Correspondence to: A. Sakai (shakai@nagoya-u.jp)

Received: 11 June 2014 - Published in The Cryosphere Discuss.: 11 July 2014

Revised: 17 February 2015 - Accepted: 25 March 2015 - Published: 6 May 2015

\begin{abstract}
Among meteorological elements, precipitation has a large spatial variability and less observation, particularly in high-mountain Asia, although precipitation in mountains is an important parameter for hydrological circulation. We estimated precipitation contributing to glacier mass at the median elevation of glaciers, which is presumed to be at equilibrium-line altitude (ELA) such that mass balance is zero at that elevation, by tuning adjustment parameters of precipitation. We also made comparisons between the median elevation of glaciers, including the effect of drifting snow and avalanche, and eliminated those local effects. Then, we could obtain the median elevation of glaciers depending only on climate to estimate glacier surface precipitation.

The calculated precipitation contributing to glacier mass can elucidate that glaciers in arid high-mountain Asia receive less precipitation, while much precipitation makes a greater contribution to glacier mass in the Hindu Kush, the Himalayas, and the Hengduan Shan due to not only direct precipitation amount but also avalanche nourishment. We classified glaciers in high-mountain Asia into summeraccumulation type and winter-accumulation type using the summer-accumulation ratio and confirmed that summeraccumulation-type glaciers have a higher sensitivity than winter-accumulation-type glaciers.
\end{abstract}

\section{Introduction}

Meltwater from glaciers and seasonal snow in the high mountains is a significant water resource in Asia (Immerzeel et al., 2010, 2013; Kaser et al., 2010). However, Asian mountains have a poor network of precipitation measurement (Bookhagen and Burbank, 2006), even though precipitation is a crucial parameter for understanding hydrological processes. In addition, meteorological stations in mountain regions are generally located at lower elevations in the valleys and thus are not representative of basin-scale precipitation because of strong orographic effects. Several gridded data sets compiling precipitation have been produced based on ground raingauge data or satellite data on a global scale (Chen et al., 2002; New et al., 2000; Huffman et al., 1997). Almost all data sets, however, do not consider orographic effects (Adam et al., 2006).

Yatagai et al. $(2009,2012)$ provided the Asian Precipitation - Highly Resolved Observational Data Integration Towards Evaluation of Water Resources (APHRODITE) gridded precipitation data set based on gauge data from 1951 to 2007. They interpolated precipitation in mountain regions by considering orographic effects on precipitation based on the parameter-elevation regressions on independent slopes model (Daly et al., 1994). The gridded data sets, however, have significant biases against point observational data in the Himalayan Mountains (Fujita and Nuimura, 2011).

Observed precipitation data at high altitude (Putkonen, 2004) are very rare in high-mountain Asia. Böhner (2006) generated high-resolution climatic data sets, radiation, temperature and precipitation in central and high Asia. He reported that there are uncertainties in annual water balance owing to methodical limits in the spatial estimation of precipitation in high-mountain Asia. Recently, Maussion et al. (2014) generated a new high-resolution atmospheric data set, High Asia Reanalysis (HAR), using the Weather Re- 
search and Forecasting (WRF) model from October 2000 to September 2011. The HAR has previously reported spatial pattern and seasonality of precipitation well. They proposed a new classification based on precipitation seasonality. Furthermore, they found glaciers of varying types over very short distances in the Himalayan ranges.

Braithwaite and Raper (2002) indicated that calibrated precipitation at equilibrium-line altitude (ELA) (Braithwaite and Zhang, 1999) using a degree-day model was considerably greater than the grid precipitation in New et al. (1999) in New Zealand, the Caucasus, the Alps, southern Norway, northern Scandinavia, Svalbard, and Axel Heiberg Island. Engelhart et al. (2012) calculated spatial distribution of glacier mass balances using gridded temperature and precipitation, and then compared the calculated distribution with observed spatial distribution. They indicated that the gridded precipitation did not represent orographic enhancement of precipitation. Rupper and Roe (2008) estimated ELA by an energy mass balance model, with NCEP/NCAR reanalysis data from high-mountain Asia, assuming all precipitation as solid. However, the estimated ELA had a large discrepancy with glacier distribution. They noted that the reanalysis temperature was a valuable estimator of summer balance, but the reanalysis precipitation was a poor estimator of winter balance. Rasmussen (2013) also pointed out that correlation between the NCEP/NCAR reanalysis precipitation values and winter balance was low. Braithwaite et al. (2006) estimated accumulation at ELA of 180 glaciers using a degreeday model, in which the modelled annual accumulation represented the observed winter balance well. Immerzeel et al. (2012) estimated detailed distribution of precipitation on the Karakoram glaciers by assuming a neutral glacier mass balance. Overall, precipitation in the gridded data still required calibration to calculate glacier mass balance, because amount and seasonality of precipitation strongly affect the sensitivity of glacier mass balance (Oerlemans and Fortuin, 1992; Braithwaite and Raper, 2002; Fujita, 2008a, b).

The objective of this study was to estimate precipitation at the ELA over Asian glaciers derived from the Glacier Area Mapping for Discharge in Asian Mountains (GAMDAM) glacier inventory (GGI) (Nuimura et al., 2015), and to evaluate the climate regime at the Asian glaciers. We confirmed that the median elevation of glaciers can be proxy data for ELA in the Asian glaciers, and we established a method for calculating precipitation at the median elevation of glaciers by applying a climatic glacier mass balance model with a reanalysis data set, so that mass balance would be zero, by tuning annual precipitation.

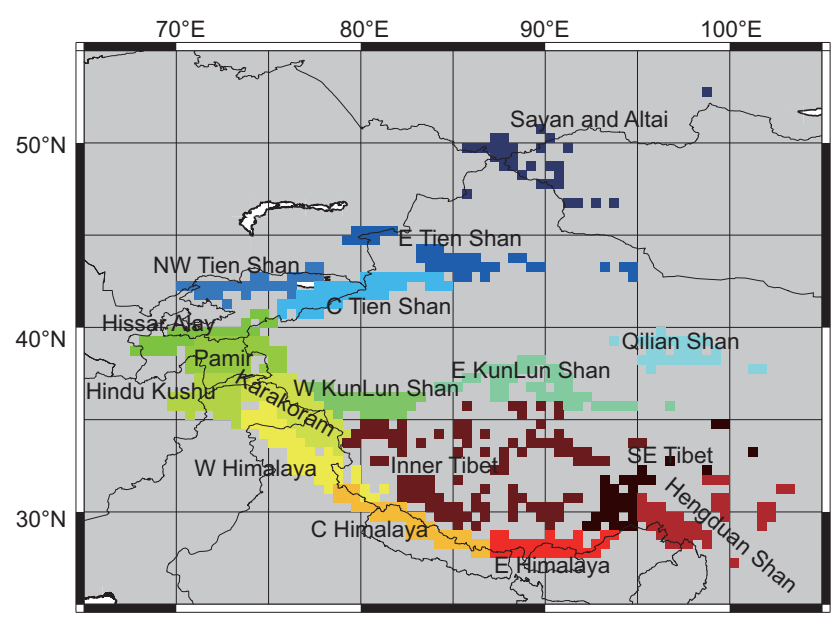

Figure 1. Study area: high-mountain Asia. Region name and location of the grid that the GGI occupied.

\section{Study region, data, and method}

\subsection{Study region}

Our study region covers high-mountain Asia $\left(26.5-55.5^{\circ} \mathrm{N}\right.$, $66.5-104.5^{\circ} \mathrm{E}$ ), which corresponds to the regions of central Asia, southwestern Asia, southeastern Asia, and Altay and Sayan of northern Asia in the Randolph Glacier Inventory (Pfeffer et al., 2014) (Fig. 1). The centre of our target region is the Tibetan Plateau, whose elevation is around $5000 \mathrm{~m}$ a.s.l. The plateau forms an orographic obstacle for westerlies and Indian monsoons. Indian monsoons supply high amounts of precipitation over the Himalaya, but most moisture is orographically forced out at elevations less than $4000 \mathrm{~m}$ a.s.l., and the high-altitude glacier area is significantly more arid (Harper and Humphrey, 2003). Monsoon moisture influence decreases from east to west along the Himalayas, and westerly moisture becomes important in the western Himalayas and the Karakoram. The moisture boundary between monsoon and westerly lies at $78^{\circ} \mathrm{E}$ near the Sutlej Valley (Bookhagen and Burbank, 2010). Westerlies can reach higher elevations than the summer monsoon, which may be related to the higher tropospheric extent of the westerly airflow (Scherler et al., 2011). Precipitation increases with altitude, and maximum precipitation occurs between 5000 and $6000 \mathrm{~m}$ a.s.l. (Wake, 1989; Young and Schmok, 1989; Young and Hewitt, 1990; Hewitt, 2011).

The Pamir Mountains, located in a transition zone, are influenced by the monsoon and the westerlies. In the eastern part, the climate is characterised as a semiarid and arid mountain climate because the area is surrounded by high mountains (Hindu Kush, Alay, Tien Shan, and Karakoram Mountains) (Zech et al., 2005). The Tien Shan Range constitutes the first montane barrier for northern and western air masses travelling from Siberia and the Kazakh steppes to central Asia. The resulting barrier effects lead to a distinct conti- 
nentality gradient with decreasing precipitation rates. Sorg et al. (2012) summarised that western and northern Tien Shan can be classified as moist regions, and central and eastern Tien Shan have a continental arid/semiarid climate. In terms of the seasonality of precipitation, maximum precipitation occurs winter in western Tien Shan, spring and early summer in northern and eastern Tien Shan, and summer in central Tien Shan.

In the Altai Range, one of the main factors that determines the climatic regime is interaction between the Siberian High and western cyclonic activity (Surazakov et al., 2007). Aizen et al. (2006a) reported that two-thirds of the accumulation come from oceanic sources (Atlantic or Arctic) and the rest was recycled over Aral-Caspian sources in the Russian Altai Mountains. The Sayan Range, located on the northwestern edge of Mongolia, is an arid/semiarid region. Precipitation in Mongolia is supplied by the synoptic-scale disturbances during the summer (June-August) because this region is in the westerly dominant zone. The region contributing to precipitation in Mongolia is western Siberia, located to the northwest of Mongolia (Sato et al., 2007). Most precipitation in the interior of high-mountain Asia originates from recycled evaporation, and such a proportion of continental recycling cannot be found on the other continents (Yoshimura et al., 2004). These circulation systems characterise the glaciers as summer-accumulation type and winter-accumulation type (Ageta and Higuchi, 1984; Fujita and Ageta, 2000).

Most glaciers in the Himalayas (Bolch et al., 2012) or on the Tibetan Plateau (Yao et al., 2012) are shrinking, as are glaciers in Tien Shan (Aizen et al., 2006b; Narama et al., 2010; Sorg et al., 2012) and Altai (Surazakov et al., 2007), while glaciers in the Karakoram are in a state of slight mass gain (Gardelle et al., 2013). Furthermore, recent analyses by Kääb et al. (2012, 2015), Gardner et al. (2013), and Neckel et al. (2014) elucidated that the glacier fluctuations have contrasting behaviours in Asia by repeat ICESat (Ice, Cloud, and land Elevation Satellite) tracks analysis. Fujita and Nuimura (2011) also indicated that the fluctuation of glaciers in high-mountain Asia were spatially heterogeneous, based on calculated ELA with reanalysis data sets.

\subsection{Median elevation and ELA derived from GGI}

The GGI is a quality-controlled glacier outline based on the Landsat level 1 terrain-corrected (L1T) scenes, which were delineated manually (Nuimura et al., 2015). Because systematic geometric corrections are performed for the L1T products, the GGI can provide precise hypsometry of glaciers.

ELA is defined as the elevation of zero mass balance. Several researchers have proposed different methods for estimating ELA, such as the shape of contour lines and the accumulation area ratio (AAR) method (Torsnes et al., 1993; Benn and Lehmkuhl, 2000; Carrivick and Brewer, 2004). Braithwaite and Raper (2009) demonstrated the median elevation of 94 glaciers in the World Glacier Inventory (WGI), each

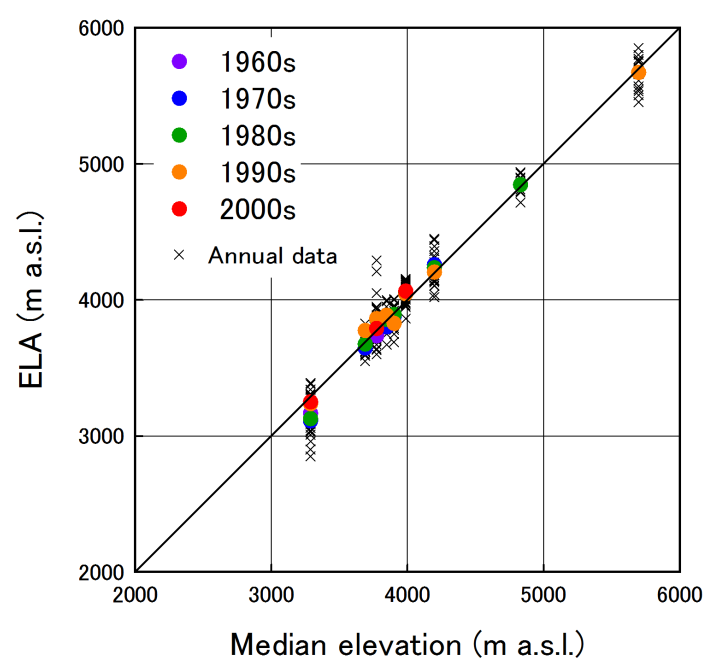

Figure 2. Relation between median elevation derived from the GGI and annual observed ELAs (cross marks) and decadal average of observed ELA (coloured circles) on nine glaciers in high-mountain Asia.

with balanced-budget ELA, i.e. an elevation of zero mass balance for a particular glacier. They showed that median elevations of glaciers (where elevation divides glacier area equally) are available for balanced-budget ELA. Bolch et al. (2012) (Fig. S2 in the Supplement) (Himalaya), Paul et al. (2002) (Swiss Alps), Rastner et al. (2012) (Greenland), and Racoviteanu et al. (2008) (Cordillera Blanca in Peru) also show median elevations in each region as an indicator of ELA. In the GLIMS glacier inventory, median elevation is an important basic parameter derived by compiling the glacier polygon data and a digital elevation model (Paul et al., 2009).

We compared the few observed ELAs with the median elevation derived from the GGI (Nuimura et al., 2015) using ASTER GDEM (ver. 2) extracted by $30 \mathrm{~m} \times 30 \mathrm{~m}$ grid cells (Table S1 in the Supplement). Nine glaciers were observed, and the average observed period was 29 years. Figure 2 indicates that decadal ELAs are consistent with the median elevation of each glacier $(\operatorname{RMSE}=71$; bias $=+3)$, whereas annual ELAs vary widely $($ RMSE $=114)$. Nuimura et al. (2015) also indicated that distribution of the snow line altitude (SLA) of glaciers in China reported by Shi (2008) also corresponded well with the median elevation of glaciers derived from the GGI. Those SLAs were estimated from topographic maps by contour inflection (convex in accumulation area and concave in the ablation area) or from aerial photos by average height of the firn area margin.

\subsection{Median elevation of glaciers as proxy data for ELA}

Drifting snow provides a significant contribution to glacier accumulation and affects the present glacier distributions (Jaedicke and Gauer, 2005). Avalanche snow from ice-free 
slopes is also an important source of glacier accumulation in precipitous terrains (Benn and Lehmkuhl, 2000; Hewitt, 2014). Thus, ELA and median elevation of glaciers are affected not only by temperature and precipitation but also by those alternative sources of glacier nourishment.

Here, we set three averaged median elevations of glaciers: G-average elevation, L-average elevation, and W-average elevation. We calculate average elevation of glaciers in each $0.5^{\circ} \times 0.5^{\circ}$ grid by area-weighted averages of median elevation for individual glaciers. The resolution corresponds with that of the precipitation data set (APHRODITE).

\subsubsection{G-average elevation}

Small glaciers have a large variation of median elevation because they have an upper or lower distribution when separating from main large glaciers. Furthermore, small glaciers have relatively short response time to climate change (i.e. they would not have recorded climate in the past few decades). Hence, to represent the median elevation of large glaciers in each grid cell, we calculate median glacier elevation, area-weighted average in each $0.5^{\circ}$ grid using the GGI in high-mountain Asia. The minimum glacier area is $0.05 \mathrm{~km}^{2}$ (Nuimura et al., 2015). Here, we define the simple median glacier elevation as G-average elevation.

\subsubsection{L-average elevation}

Some median elevations of glaciers averaged in each grid reflect only a few small glaciers. Small glaciers in undulating terrain are strongly dependent upon drifting snow and cannot maintain snow or ice mass without drifting snow. Those small glaciers can exist at much lower altitudes than large glaciers. Therefore, we analysed the representativeness of each median elevation of glaciers and the glaciers using the GGI.

Median anomaly is the difference between the median elevation of each glacier and the average median elevation of the glaciers in the vicinity. The glaciers in the vicinity were defined as glaciers located inside the $0.5^{\circ} \times 0.5^{\circ}$ grid, with the centre on the location of the glacier, which is defined at the centre of gravity of each glacier. Figure 3 a shows that glaciers with a smaller area have large variability of median anomaly. Here, we selected those glaciers with more than 300 glaciers in the vicinity $\left(0.5^{\circ} \times 0.5^{\circ}\right.$ grid $)$. In particular, glaciers smaller than $1 \mathrm{~km}^{2}$ in area have large standard deviations ( $\mathrm{SD}>230 \mathrm{~m}$ ) of the median anomaly, and the number of outliers $(2 \sigma)$ is more than 18000 , whereas glaciers larger than $1 \mathrm{~km}^{2}$ have fewer than 300 outliers (Fig. 3b). This means that smaller glaciers are affected by local terrain.

Dahl and Nesje (1992) reported that ELA depression of cirque glaciers is caused by leeward accumulation. Conversely, the windy side of cirque glaciers tends to have higher ELA because of denudation of deposited snow. Furthermore, small glaciers with high median anomalies might be glaciers

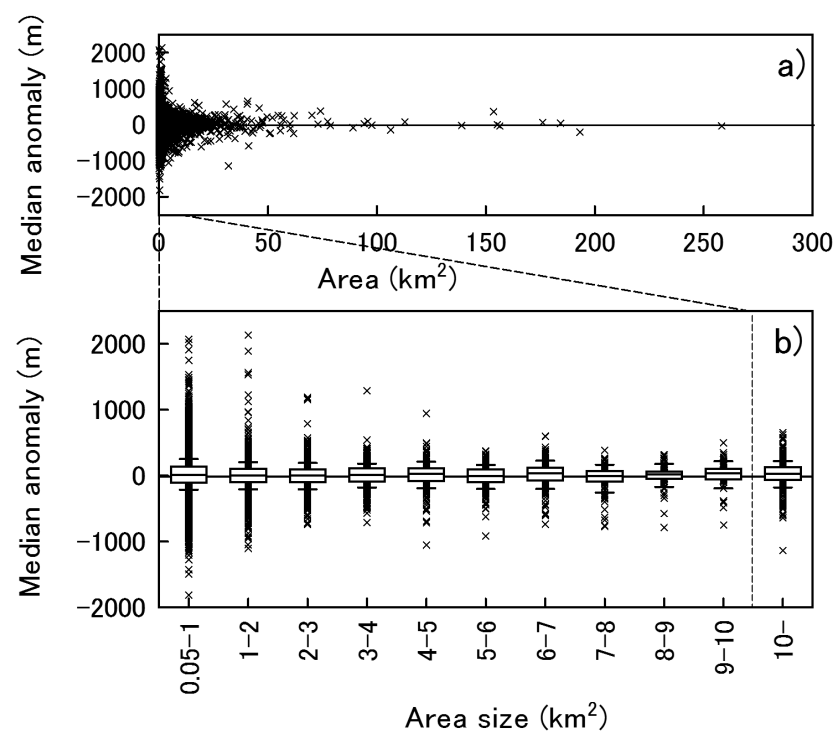

Figure 3. (a) Relation between glacier area and median anomaly, which has glaciers with more than 300 glaciers in the vicinity (within $0.5^{\circ} \times 0.5^{\circ}$ grid). (b) Median anomaly distribution in $1 \mathrm{~km}^{2}$ bins up to $10 \mathrm{~km}^{2}$. Boxes give lower and upper quartiles of median glacier altitude in $1 \mathrm{~km}^{2}$ bin. Vertical error bars indicate standard deviation of data range. Crosses lie outside of this range.

separated from ablation areas, and those with low median anomalies might be composed of drift snow accumulated by a depression. Those with large anomalies of median elevation can be explained by redistribution of snow because of wind effect or topography.

Thus, G-average elevations of glaciers are affected by local terrain, in particular, in the grid with only small glaciers. Here, we propose L-average elevation, which is calculated by excluding glaciers smaller than $1 \mathrm{~km}^{2}$ in area.

\subsubsection{W-average elevation}

Each median elevation of glaciers is sometimes affected by the geography surrounding the glacier. Scherler et al. (2011) introduced percentage of ice-free areas in the accumulation area and contributing headwalls as a proxy for the relative importance of avalanche accumulation, and they reported that avalanche-fed glaciers (the percentage of ice-free areas in the accumulation area and contributing headwalls of a given glacier) have a lower median elevation against snow line elevation in the Himalayas. Steep avalanche walls, at which snow cannot be retained at the surface, were excluded from the GGI (Nuimura et al., 2015). The median elevation of avalanche-fed glaciers would be lowered by the amount of avalanche snow accumulation, which should accumulate at the steep avalanche wall. Then, the median elevation of avalanche-fed glaciers calculated from area-altitude distribution, including glaciers as well as steep avalanche walls, would reflect ELA, depending only on temperature and pre- 
cipitation (not affected by avalanche nourishment). Sensitivity of glacier mass balance to temperature change requires ice or snow mass accumulating on the glacier, including not only direct precipitation but also avalanche nourishment. Furthermore, the relation between direct precipitation and ice or snow mass accumulating on the glacier is significant for calculation of glacier mass fluctuation. To estimate direct precipitation on glaciers, we tried to estimate the median elevations of glaciers, including steep avalanche walls. Figure S1 shows an example of the estimation of averaged median elevations of glaciers, including steep avalanche walls. We assumed that hypsometry of steep avalanche walls can be estimated by linear interpolation between the area at the altitude of maximum glacier area and maximum ground altitude, at which area is assumed to be zero. Then, the averaged median elevation of glaciers, including avalanche walls, became $6125 \mathrm{~m}$ (W-average) from $5394 \mathrm{~m}$ (L-average). Here, we define the elevation as $\mathrm{W}$-average elevation. When glacier hypsometry higher than median elevation has a strong convex curve, the L-average elevation exceeds the $\mathrm{W}$-average elevation. In this case, $\mathrm{W}$-average elevation is assumed to be equal to L-average elevation. The total number of grids that have an average elevation different from L-average elevation is 413 .

\subsection{Meteorological data}

\subsubsection{Comparison between observed data and reanalysis data set}

Ablation of glaciers depends on several elements, such as snow, albedo of the glacier surface, air temperature, solar radiation, and longwave radiation. Fujita and Ageta (2000) concluded that the air temperature, and solar radiation are the major elements for calculation of glacier ablation. Therefore, daily reanalysis data, air temperature and solar radiation from NCEP/NCAR (Kalnay et al., 1996) and ERA-Interim (Dee et al., 2011) have been compared with the observed data on or adjacent to glaciers in high-mountain Asia (Fig. S2). Analysed site names, locations, and observed periods are summarised in Table S2. Observed meteorological data by automatic weather station (AWS), in particular, on the glacier or near the terminus of the glacier are very rare in high Asian mountains. We did not select the observed site, and those daily data are all the data available to us. Air temperature at each AWS $\left(T_{o}\left[{ }^{\circ} \mathrm{C}\right]\right)$ were calculated assuming that the free-atmosphere air temperatures at each elevation $\left(z_{o}[\mathrm{~m}]\right)$ (Table S2) are as follows:

$T_{z}=T_{1}+\left(\frac{T_{2}-T_{1}}{z_{2}-z_{1}}\right) \times\left(z_{o}-z_{1}\right)$.

Lapse rate of air temperature is estimated by the temperatures at the two closest geopotential heights $\left(z_{1}, z_{2}[\mathrm{~m}]\right)$ containing the elevation of the AWS (i.e. $z_{1} \leq z_{0} \leq z_{2}$ ). $T_{1}$ and $T_{2}$ $\left({ }^{\circ} \mathrm{C}\right)$ indicate reanalysis air temperatures at each geopotential height, $z_{1}$ and $z_{2}$, respectively.
We compared only summer season (JJA) data, because snow cover on the sensors of the instruments tends to impede precise measurement during the winter. Furthermore, calculation of ablation during the melting season has a larger effect on glacier mass balance. Both root mean square errors (RMSEs) of solar radiation and temperature between reanalysis and observed data were less for the ERA-Interim. Therefore, we used ERA-Interim for calculation of glacier mass balance, as described in the next section.

\subsubsection{Reanalysis data used}

Daily ERA-Interim reanalysis data (Dee et al., 2011) - including temperature (level), geopotential height (level), surface wind (surface flux $10 \mathrm{~m}$ ), surface humidity (surface), and solar radiation (surface flux) - from 1952 to 2007 were used to calculate glacier mass balance. The spatial resolution was $0.75^{\circ} \times 0.75^{\circ}$, and all pressure levels of the temperature and geopotential height data from 300 to $850 \mathrm{hpa}$ (300, $350,400,450,500,550,600,650,700,750,775,800,825$, and 850), which cover all average elevations of each grid, were used. Daily temperatures are given at each average elevation of glaciers, where lapse rate of air temperature is estimated by the temperature at two geopotential heights bounding/containing the average elevation according to Eq. (1) $\left(z_{o}\right.$ should be average elevation for calculation of precipitation). Daily precipitation data, APHRODITE from 1952 to 2007, with spatial resolution of $0.5^{\circ} \times 0.5^{\circ}$ were also used to calculate glacier mass balance.

\subsection{Climatic glacier mass balance model}

The climatic glacier mass balance model, based on the heat balance method provided by Fujita and Ageta (2000) and Fujita et al. (2007, 2011), was used to calculate mass balance at all three median elevation categories (G-, L-, and Waverage elevations), which are the area-weighted average in each $0.5^{\circ} \times 0.5^{\circ}$ grid. Daily heat balance at glacier surface can be calculated using the following: required air temperature; relative humidity; wind speed; solar radiation; precipitation; and mass balance consisting of snow accumulation, melt, refreezing, and evaporation, such that

$Q_{\mathrm{M}}=(1-\alpha) R_{\mathrm{S}}+R_{\mathrm{L}}-\sigma T_{\mathrm{S}}^{4}+Q_{\mathrm{S}}+E_{\mathrm{V}} l_{\mathrm{e}}+Q_{\mathrm{G}}$.

$Q_{\mathrm{M}}, \alpha, R_{\mathrm{S}}, R_{\mathrm{L}}, \sigma, T_{\mathrm{S}}, Q_{\mathrm{S}}, E_{\mathrm{V}} l_{\mathrm{e}}, l_{\mathrm{e}}$, and $Q_{\mathrm{G}}$ are heat for melting, surface albedo, downward shortwave radiation, downward longwave radiation, the Stefan-Boltzmann constant, surface temperature in Kelvin, sensible heat flux, latent heat flux, latent heat for evaporation of water or ice, and conductive heat flux into the glacier ice, respectively. All heat components are positive when fluxes are directed toward the surface. Longwave radiation was calculated by application of the equation established by Kondo and Xu (1997) using dew point temperature at the screen height and a coefficient related to the sunshine ratio (ratio of downward shortwave 
radiation to solar radiation at the top of the atmosphere). The surface temperature is obtained to satisfy all heat balance equations by iterative calculation of conductive heat. Mass balance $\left(M_{\mathrm{b}}\right)$ on the glacier is calculated as follows:

$M_{\mathrm{b}}=C_{\mathrm{a}}-Q_{\mathrm{M}} / l_{\mathrm{m}}+E_{\mathrm{V}}+R_{\mathrm{F}}$.

$C_{\mathrm{a}}, l_{\mathrm{m}}, E_{\mathrm{V}}$, and $R_{\mathrm{F}}$ are solid precipitation, latent heat for melting ice, condensation (if $E_{\mathrm{V}}$ has negative value, it is evaporation), and refreezing, respectively. This climatic mass balance model also takes into account refreezing amounts from ice temperature change, as shown in Eq. (2). Calculation interval was daily.

The phase of precipitation, solid (snow) $\left(C_{\mathrm{a}}\right.$, positive sign) or liquid (rain), depending on air temperature, is important for glacier mass balance. Precipitation $\left(P_{\mathrm{p}}\right)$ is separated solid and liquid by temperature, assuming the occurrence probability of solid precipitation. The following relation between the probability of snowfall and air temperature was obtained from data observed by Fujita and Nuimura (2011) on the Tibetan Plateau:

$$
\begin{array}{ll}
C_{\mathrm{a}}=P_{\mathrm{p}} & {\left[T_{\mathrm{a}} \leq 0\right]\left({ }^{\circ} \mathrm{C}\right)} \\
=\left(1-\frac{T_{\mathrm{a}}}{T_{1}}\right) P_{\mathrm{p}} & {\left[0<T_{\mathrm{a}}<T_{1}\right]\left({ }^{\circ} \mathrm{C}\right) \text { and }} \\
=0 & {\left[T_{\mathrm{a}} \geq T_{1}\right]\left({ }^{\circ} \mathrm{C}\right) .}
\end{array}
$$

Here, $T_{1}$ is the temperature at which all precipitation becomes liquid (rain), which was assumed to be $4{ }^{\circ} \mathrm{C}$. First, we calculated the mass balance at each average elevation using APHRODITE and reanalysis ERA-Interim data from 1979 to 2007, assuming that the initial values of ice temperature and snow depth are annual mean temperature and $0.1 \mathrm{~m}$, respectively. The ice temperature was set to $0^{\circ} \mathrm{C}$ when the annual mean exceeded the melting point. Then, we could obtain initial condition values of ice temperature and snow depth for subsequent mass balance calculations from 1979 to 2007. To calculate optimised precipitation at average elevations $\left(P_{\text {cal }}\right)$, we calculated, assuming that mass balance from 1979 to 2007 should be equal to 0 by adjusting the APHRODITE precipitation data $\left(P_{\text {ap }}\right)$ as shown in Fig. 4 ,

$P_{\text {cal }}=A_{\mathrm{p}} \times P_{\text {ap }}$,

where $A_{\mathrm{p}}$ is the adjusting ratio of APHRODITE precipitation and $A_{\mathrm{p}}$ is constant for each grid. Both $P_{\text {cal }}$ and $P_{\text {ap }}$ include all phases of precipitation (i.e. liquid and solid precipitation) in Eq. (5). Separated solid precipitation contributes to glacier mass balance. If a snow layer is on the glacier ice, and if the temperature of the snow-covered ice layer is lower than $0^{\circ} \mathrm{C}$, some amount of rain (liquid precipitation) and meltwater will refreeze on the ice layer, and that amount corresponds with the heat of the increasing ice temperature. The refrozen ice also contributes to the mass balance of the glacier. If there is no snow layer on the glacier surface, or if the ice has a $0^{\circ} \mathrm{C}$ temperature, liquid precipitation and meltwater will be released as discharge, and the discharge does not contribute to the mass balance of the glacier.

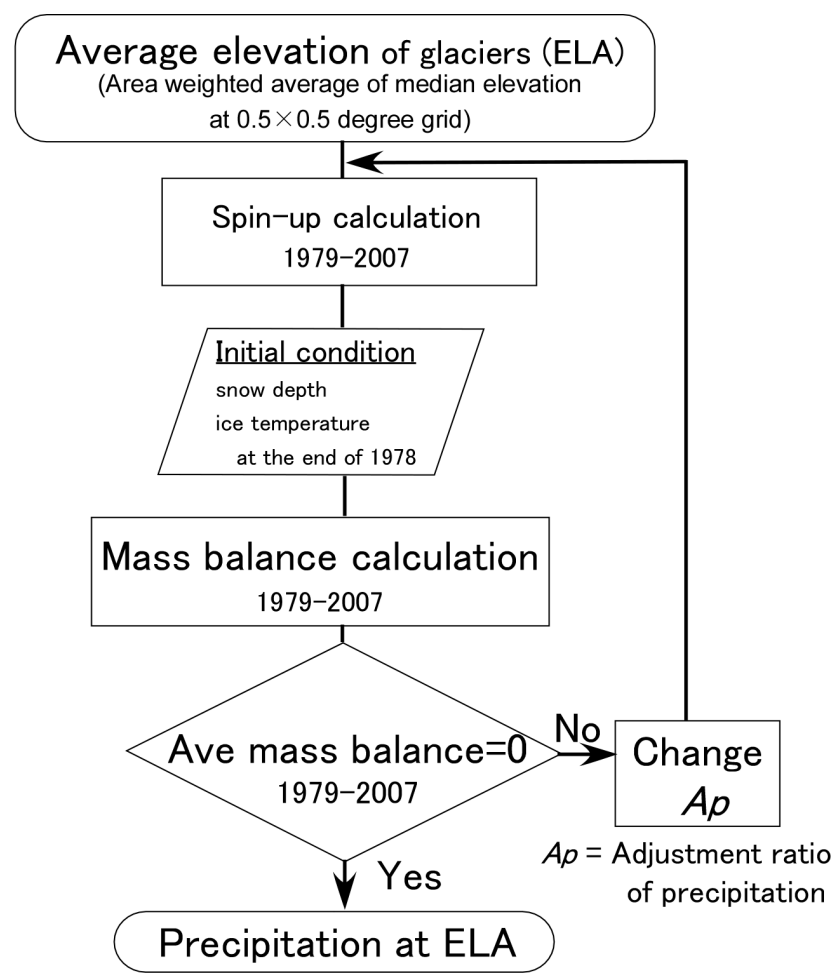

Figure 4. Flowchart of calculation of precipitation at average elevation of glaciers.

\section{Results}

\subsection{Distribution of average elevations of glaciers}

Figure 5 shows the distribution of three types of average elevations of glaciers (G-, L-, W-average elevations). The Gaverage elevations have 951 grid points, and the L- and $\mathrm{W}$ average elevations have 670 grids. Several grid cells in the eastern Sayan Mountains, in the west of the Altai Mountains, in the Qilian Mountains, and in the east of Hengduan Shan (see location in Fig. 1) in Fig. 5a (G-average elevation) have been excluded in Fig. 5b (L-average elevation) because those glaciers are smaller than $1 \mathrm{~km}^{2}$ in area.

Distribution of the difference between $\mathrm{W}$-average elevation and L-average elevation (Fig. S3) indicates that the Tibetan Plateau has less difference. The Karakoram, the Himalaya, and the Hengduan Shan have relatively large differences, which reflect that glaciers in these regions are surrounded by steep avalanche walls at the upper part. The relation between G- and L-average elevations (Fig. S4) indicates that median elevations changed both positively and negatively by eliminating small-sized glaciers $\left(<1 \mathrm{~km}^{2}\right)$.

In contrast, the average elevation of glaciers shifts to higher altitude by taking into account steep avalanche walls, which are depicted by the relation between G- and W-average elevations. Furthermore, the change of average elevation of 

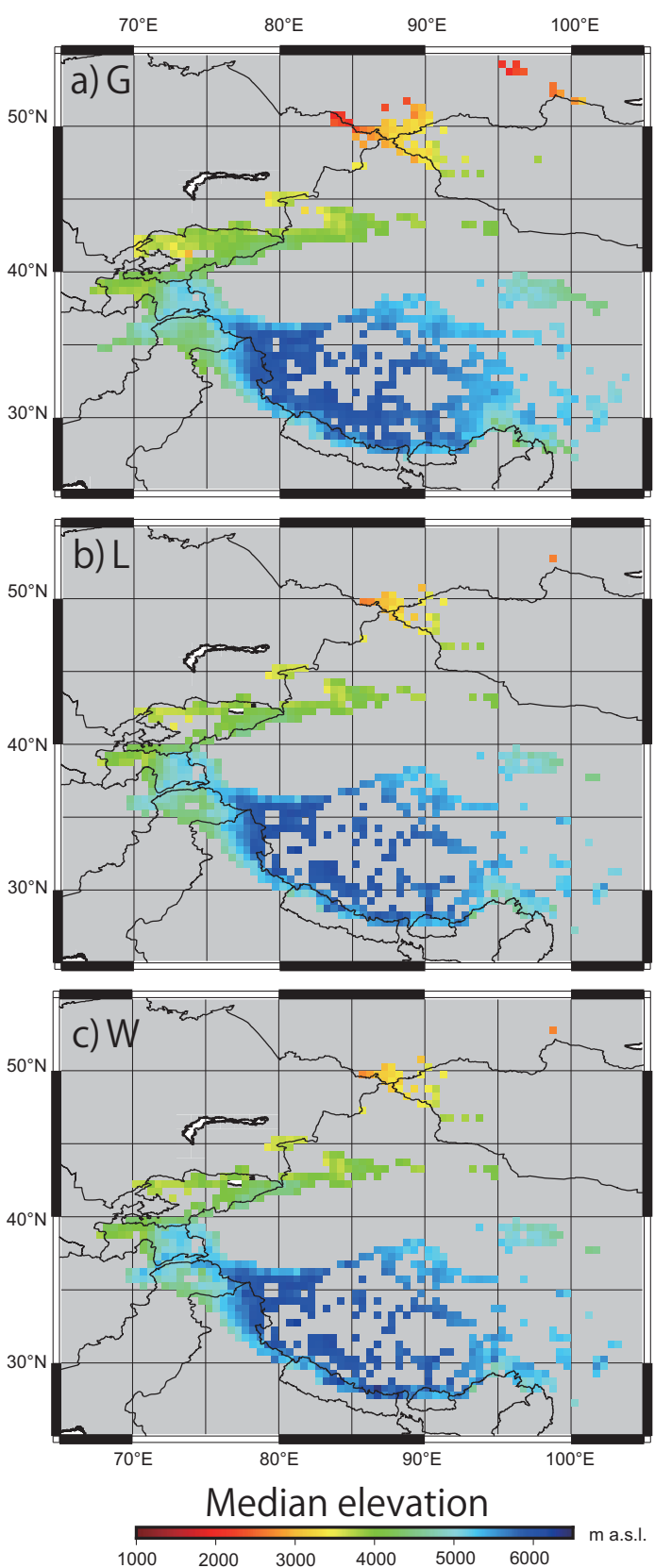

Figure 5. Distributions of (a) G-, (b) L-, and (c) W-average elevation. These distributions are the area-weighted average of median elevations in each $0.5^{\circ}$ grid.

glaciers between G- and L-average is much larger than that between $\mathrm{G}$ - and $\mathrm{W}$-average.

\subsection{Precipitation contributing to mass balance at ELA}

Figure 6 shows the annual precipitation of APHRODITE and calculated precipitation $\left(P_{\text {cal }}\right.$ in Eq. 5) at average elevation derived from the G-, L-, and W-average elevations (Fig. 5). Here these calculated precipitation amounts, which contribute to glacier mass at the G-, L-, and W-average ele- vations, are indicated by $P_{\mathrm{G}}, P_{\mathrm{L}}$, and $P_{\mathrm{W}}$, respectively. Little precipitation around the Taklimakan Desert and much precipitation at the Hengduan Shan and the southern edge of the western Himalayas, the Hindu Kush, and the Hissar Alay were found. These calculated precipitations at ELA reflect the regional climate in high-mountain Asia. Furthermore, they might include inconsistency between average elevation of glaciers and ELA. However, several grids have extraordinarily large amounts of precipitation in the eastern Sayan Mountains, the west of the Altai Mountains, the southern edge of the Himalayas, and the Hengduan Shan (Fig. 6b). Although $P_{\mathrm{L}}$ in Fig. 6c in several grids at the Hengduan Shan, the southern edge of the Himalayas, and the Karakoram was still extremely large, those grids have less $P_{\mathrm{W}}$ in Fig. 6d. Figure S5 shows the difference of $P_{\mathrm{L}}$ to $P_{\mathrm{W}}$. The difference implies the amount of avalanche nourishment contribution. A difference of more than $500 \mathrm{~mm}$ is found at high relief terrains, such as the central and eastern Himalayas, the Hengduan Shan, the Karakoram, and the Hissar Alay. Thus, large amounts of avalanche nourishment would contribute to the glacier mass in those regions. Still, several grids have extremely large precipitation compared with adjacent grids. Those overestimations would be caused by missed glacier delineation or unreasonable estimation of the steep avalanche wall.

\subsection{Evaluation}

Although direct observations of precipitation at ELA are scarce, winter balance was observed at several glaciers in high-mountain Asia, as compiled by Dyurgerov (2002) (Table S3). We compared the snow amounts calculated from 1979 to 2000 at the G-, L-, and W-average elevations with observed winter balances, using the value from the corresponding grid cell (Fig. 7) (Table S4). APHRODITE snow was calculated by use of daily temperature at each ELA based on Eq. (4). The figure shows APHRODITE snow is significantly less than the observed winter accumulation. Furthermore, snow amount derived from G-, L-, and $\mathrm{W}$-average elevations tends to be smaller than the winter balance, but the correlation coefficient is statistically significant and much higher than that with APHRODITE snow.

Accumulated snow at the end of winter is reported as "winter balance" in the report of Dyurgerov (2002). The highest correlation coefficient between average observed winter balance and accumulation calculated on the basis of L-average elevation is obtained, although the correlation coefficient between observed winter balance and calculated precipitation based on $\mathrm{W}$-average elevation was low. The reason behind this finding might be the fact that observed winter balance includes not only surface precipitation but also avalanche nourishment during winter. Thus, observed winter balance can be a validation for accumulation during winter, including drifting snow and avalanche. However, it cannot be a validation for direct precipitation during winter. 

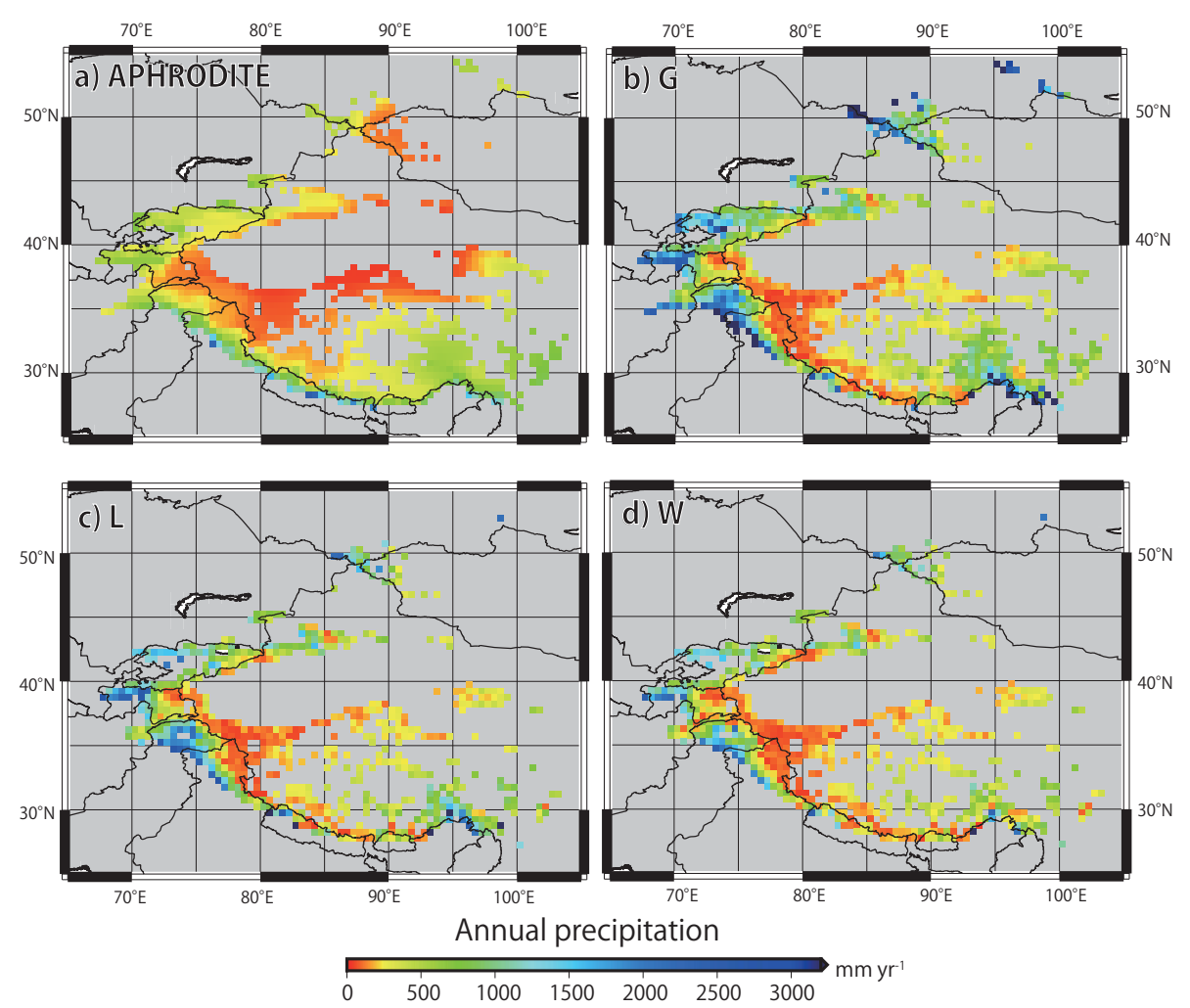

Figure 6. Annual solid and liquid precipitation of APHRODITE averaged from 1979 to 2007 (a), at which a glacier was located in the GGI. Calculated annual precipitation assumed to accumulate on glacier surfaces based on (b) G-, (c) L-, and (d) W-average elevations.

We also plotted errors of calculated snow amount caused by input parameters, temperature, $T_{1}$ in Eq. (4), solar radiation, and average elevation (Fig. S6). Ranges of air temperature $\left( \pm 0.9^{\circ} \mathrm{C}\right)$ and solar radiation $\left( \pm 102 \mathrm{~W} \mathrm{~m}^{-2}\right)$ were from RMSEs between observed data and ERA-Interim data during the summer (JJA), as shown in Fig. S2. The range of $T_{1}$ was taken as $\pm 2{ }^{\circ} \mathrm{C}$, the source of which is described in the next section. The range of average elevations comes from the RMSE between observed ELA and average elevation, as shown in Fig. 2. Figure S6 shows that error of calculated snow caused by solar radiation was the largest parameter among those input parameters.

\section{Discussion}

\subsection{Index of median elevation of glaciers}

\subsubsection{Bias of median elevation derived from GAMDAM glacier inventory}

In the GGI, we excluded steep slope areas, where snow cannot accumulate, from the glacier area (Nuimura et al., 2015). Thus, the median elevation derived from the GGI would have lower elevations than those based on a glacier inventory that included steep head walls. Bajracharya and Shrestha (2011) created the International Centre for Inte- grated Mountain Development (ICIMOD) inventory covering the Hindu Kush-Himalayan (HKH) region (Amudarya, Indus, Ganges, Brahmaputra, and Irrawaddy river basins). This inventory was generated semi-automatically using more than 200 Landsat 7 ETM+ images taken between 2002 and 2008. Nuimura et al. (2015) compared median elevations averaged in each grid cell by area-weighting our GGI and the ICIMOD glacier inventory in the HKH region (Fig. 14c in Nuimura et al., 2015). Mean average elevations based on the GGI was $34 \mathrm{~m}$ lower than those of the ICIMOD glacier inventory in the HKH region. This difference is within the RMSE (71 $\mathrm{m}$ ) between the median elevation and observed ELA. Regional distribution of average elevation difference between the ICIMOD inventory and the GGI is especially large in the Pamir Range (approximately $300 \mathrm{~m}$ ) (Fig. 15c in Nuimura et al., 2015). Thus, estimated precipitation by use of G- and L-average elevation in the Pamir Range would be overestimated.

\subsubsection{Potential bias of median elevation and $\mathrm{W}$-average elevation}

We assumed that the median elevation of glaciers corresponds with the multi-decadal average of ELA on the basis of Fig. 2. However, there are only nine observed glaciers, with limited observed periods. Thus, we have to consider 


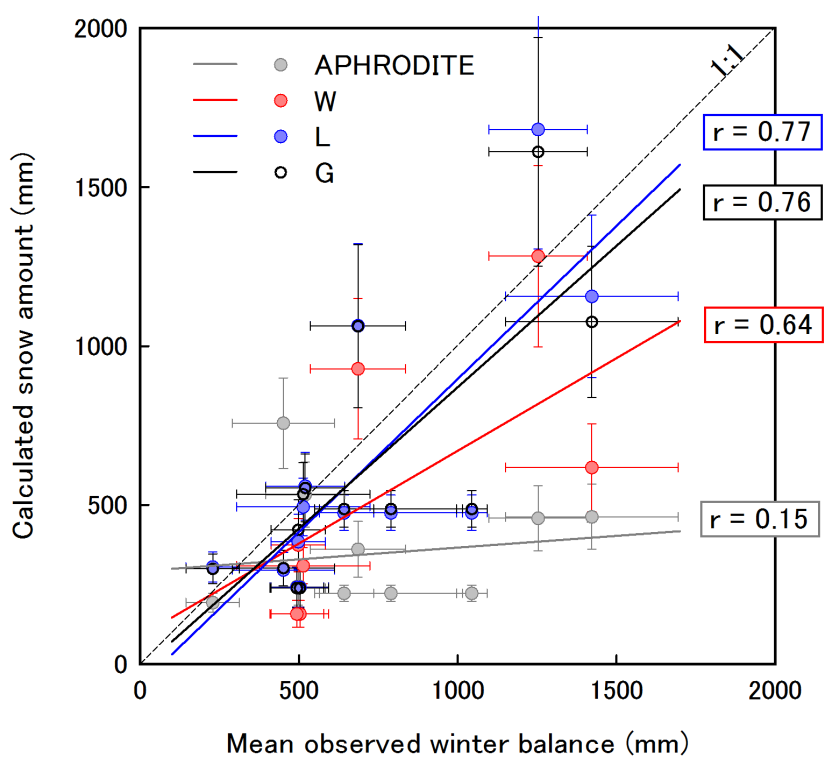

Figure 7. Relation between observed winter balance averaged from 1979 to 2000 and calculated snow amounts. Grey circles indicate the snow amounts calculated from APHRODITE. Hollow small circles, blue circles, and red circles show those snow amounts calculated from precipitation based on G-average elevation, L-average elevation, and $\mathrm{W}$-average elevation, respectively. Both vertical and horizontal error bars indicate standard deviation of each annual value. RMSE, correlation coefficient, and significance level between observed data and calculated snows are listed in Table S3.

the discrepancy between ELA and the median elevation of glaciers in each region. Scherler et al. (2011) reported on regional AARs in high Asian mountains, which estimated the snow line altitude by use of satellite images acquired near the end of the hydrological year. They summarised that glaciers in the Karakoram, northern central Himalayas, and western Kunlun Shan have larger AARs $(>0.5)$. Thus, we can estimate that median elevations (i.e. AAR $=0.5$ ) of those glaciers correspond to elevations with positive mass balance, which suggests that calculated precipitation at median elevation would be underestimated. Glaciers in the Hindu Kush, western Himalayas, and southern central Himalayas have less AAR $(<0.5)$ according to Scherler et al. (2011), which indicates that the median elevation of those glaciers corresponds to the elevations with negative mass balance. Thus, calculated precipitations at median elevations in those regions would be overestimated.

We estimate $\mathrm{W}$-average elevation by assuming that the maximum altitude of the ground in the grid cell corresponds to the highest altitude of glacier basins. For a more ideal estimation of W-average elevation, we should calculate them in every basin, not every grid cell, because mountain peaks at glacier headwalls sometimes sort out different grid cells from those glaciers. Those missed segmentations of glaciers and mountain peaks would lead to under/overestimation of W-average elevation. For example, grid B (Fig. 12) with ex-

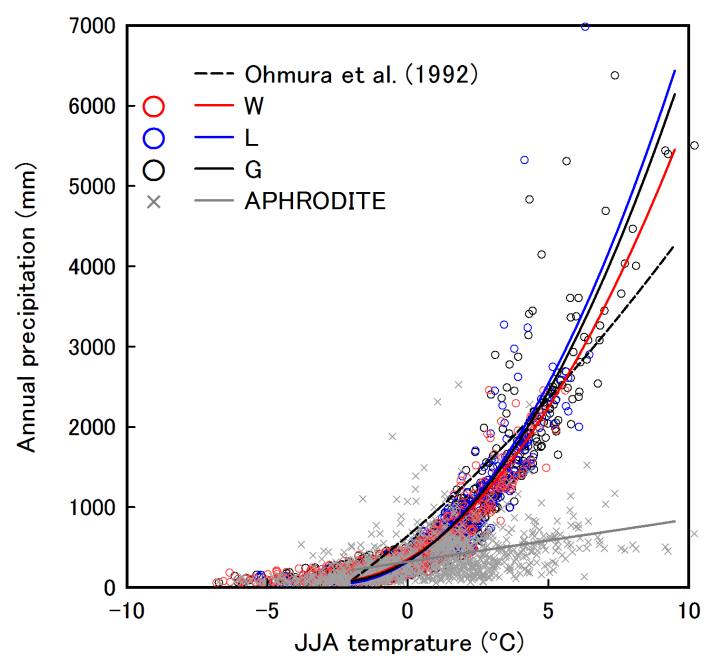

Figure 8. Relation between summer (JJA) temperature and annual precipitation at G-average (black circles), L-average (blue circles), and W-average (red circles) elevations and APHRODITE averaged from 1979 to 2007 (grey crosses). Fitted curves of each data set are plotted and shown by the respective colour. The fitted curve derived by Ohmura et al. (1992) is shown by the black dashed line.

tremely large $A_{\mathrm{p}}$ would be explained by underestimation of $\mathrm{W}$-average elevation by those missed segmentations (see details in Sect. 4.3).

\subsection{Climate on average elevation of glaciers}

\subsubsection{Relation between temperature and precipitation at average elevation}

Several researchers have analysed the relation between summer (JJA) temperature and annual precipitation at ELA (T-P plot) and discussed climatology of glaciers (e.g. Nesje and Dahl, 2000). Ohmura et al. (1992) established the relation between summer (JJA) temperature and annual precipitation at ELA (T-P plot) for 70 glaciers in the world. Braithwaite et al. (2006) also discussed the effect of vertical lapse rate for temperature based on the observed winter balance and model annual temperature sum of 180 glaciers in the world. T-P plots can show the climate regime of glaciers, and the slope of the T-P can indicate the sensitivity of glaciers to temperature change (Ohmura et al., 1992).

The T-P plot in Fig. 8 indicates that APHRODITE precipitation cannot represent the relation reported by Ohmura et al. (1992). We also depict T-P plots at G-, L-, and W-average elevations in each grid in Fig. 8. The T-P plot of G-average elevation includes high-temperature range $\left(5-10^{\circ} \mathrm{C}\right)$. The reason for this finding is that G-average elevation reflects the elevation of small glaciers composed by drifting snow in several tens of grids. T-P plots of L-average elevations contain very large precipitation in the $3-5^{\circ} \mathrm{C}$ temperature range, because glacier mass is affected by avalanche, particularly 
in the Hengduan Shan, the Himalayas, and the Karakoram. Those fitted curves of G- and L-average have a larger inclination than Ohmura's equation at the high-temperature range. On the other hand, the fitted curve of the T-P plot based on W-average elevation corresponds well with Ohmura's equation, which implies that calculated precipitation based on Waverage elevation represents reasonable results.

The T-P plot with error is shown in Fig. S7. Error was derived from RMSE of $71 \mathrm{~m}$ between the decadal average of ELA and the median elevation of each glacier (Fig. 2). Then, both vertical and horizontal error bars were calculated, assuming that L-average elevation has a $\pm 71 \mathrm{~m}$ error. Errors at median elevation increase with precipitation. Those tendencies can also be found in the precipitation calculated by use of G- and W-average elevations. We did not show those errors in the figure.

\subsubsection{Error of calculated precipitation caused by input data}

We have calculated not only precipitation errors at median elevation but also several possible errors of the calculated precipitation at average elevation because of other input data. We assumed that annual air temperature and solar radiation have errors of RMSE between observation and reanalysis data. The temperature at which the probability of solid precipitation becomes $100 \%$ is approximately $0{ }^{\circ} \mathrm{C}$. On the other hand, the critical temperature at which the probability of solid precipitation becomes $0 \%$ has a wide range, between 3 and $7^{\circ} \mathrm{C}$, according to previous research at the Tibetan Plateau (Ueno et al., 1994), Nepal Himalayas (Ageta and Higuchi, 1984), and Qilian Shan (Sakai et al., 2006). The temperature at which all precipitation becomes liquid $\left(T_{1}\right)$ was assumed to be $4{ }^{\circ} \mathrm{C}$ in Eq. (4). Here, we assumed that the critical temperature for all precipitation becoming solid was fixed at $0^{\circ} \mathrm{C}$, and $T_{1}$ has a range between 2 and 6 $\left( \pm 2^{\circ} \mathrm{C}\right)$. Then, we calculated each error of precipitation at L-average elevation in each grid cell and plotted each error of precipitation against $P_{\mathrm{L}}$ in Fig. S8.

All errors have a large variation against $P_{\mathrm{L}}$ and tend to increase with $P_{\mathrm{L}}$. Errors of $P_{\mathrm{L}}$ in input reanalysis data, air temperature, and solar radiation were larger than those of $P_{\mathrm{L}}$ in $T_{1}$ and average elevation. Thus, highly accurate reanalysis data provided in the future will greatly improve the accuracy of estimated precipitation at average elevation.

\subsubsection{Accumulation season and T-P plot}

Fujita (2008a, b) reported that summer-accumulation-type glaciers (SAGs) have higher sensitivity at ELA under the idealised meteorological variables. Hengduan Shan, Bhutan, Everest, and western Nepal are strongly influenced by the Indian and southeastern Asian summer monsoons, and glaciers are SAGs. On the other hand, the climate at Pamir, Hindu Kush, and Karakoram is dominated by the westerlies,

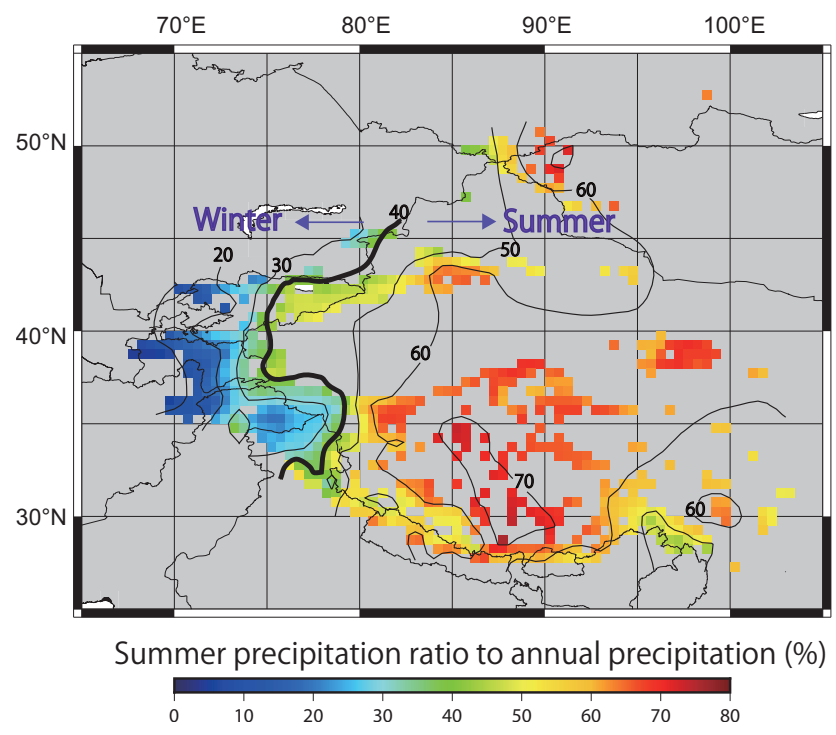

Figure 9. Distribution of summer precipitation ratio to annual precipitation from APHRODITE data. Black thick line indicates the contour of the $40 \%$ summer precipitation ratio.

and glaciers are winter-accumulation-type glaciers (WAGs) (Bookhagen and Burbank, 2010). Himachal Pradesh and Jammu Kashmir (included in the W Himalaya in Fig. 1) are transition zones, influenced by both the monsoon and the westerlies (Bookhagen and Burbank, 2010). We can classify glaciers into SAGs and WAGs using the $40 \%$ summer (JJA) precipitation ratio (SPR) to annual precipitation (APHRODITE from 1979 to 2007) in high-mountain Asia, as shown in Fig. 9.

Sensitivity of the glacier mass can be evaluated by the gradient of the relation between JJA temperature and annual precipitation at ELA (T-P plot), according to Ohmura et al. (1992). Figure 10 shows the T-P plot reported by Ohmura et al. (1992) based on 70 glaciers in the world and calculated in each grid in high-mountain Asia at W-average elevations, which are classified into WAGs and SAGs. SAGs have higher sensitivity than Ohmura's equation, particularly in the high-temperature regions. WAGs have similar sensitivity with Ohmura's equation. The reason for this finding is that Ohmura et al. (1992) established the P-T plot based mainly on WAGs. Plots of SAGs have wider variations against the fitted curve than those of WAGs (Fig. 10), which reflects that SAGs have a wider range distribution in latitude (in other words, SAGs have a wider range of summer radiation (Ohmura et al., 1992) than that of WAGs (Fig. 10)).

Braithwaite et al. (2006) also depict the T-P plot on the basis of 180 glaciers and indicate that Arctic glaciers have low (less than $0^{\circ}$ ) temperatures and less precipitation. Figure 10 also indicates glaciers with less precipitation and low temperature in high-mountain Asia, and those glaciers have less sensitivity to temperature change because high Asian mountains 


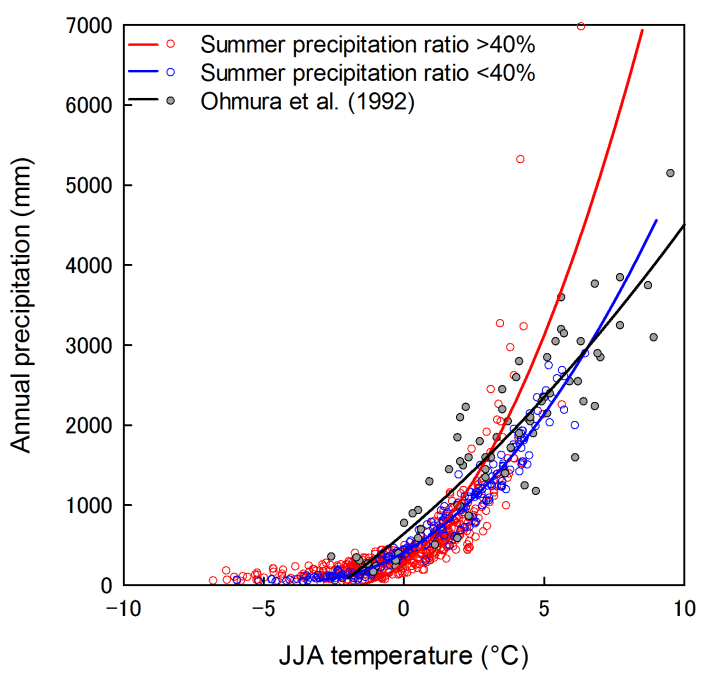

Figure 10. Relation between mean summer (JJA) air temperature and annual precipitation at L-average elevation. Red and blue circles indicate summer-accumulation-type and winter-accumulation-type glaciers, respectively. Grey circles indicate the data set reported by Ohmura et al. (1992).

contain glaciers in inland arid regions. Thus, high-mountain Asia can retain the ice mass stably, like glaciers in the Arctic.

As described above, seasonal change of precipitation is one of the important factors for mass balance in glaciers. We have analysed seasonal contribution of precipitation from APHRODITE (Fig. S9) to examine the differences among them derived from HAR (Maussion et al., 2014). The main differences of seasonal contribution between HAR and APHRODITE are in western Kunlun in JJA and MAM and Karakoram in DJF. According to Yatagai et al. (2012) (Fig. 1), gauge stations contributed to APHRODITE in the Karakoram, but very few contributed at Kunlun. Therefore, the reliability of APHRODITE data is high at Karakoram but less in the Kunlun. Glaciers in the Kunlun Shan have not been classified as SAGs on the basis of the HAR provided by Maussion et al. (2014). Less precipitation contribution during MAM and much more during JJA in the Kunlun Shan based on APHRODITE might have caused a large discrepancy in the calculated precipitation at average elevations, because MAM (spring) accumulation is important for many glaciers in high-mountain Asia (Yang et al., 2013; Maussion et al., 2014). Furthermore, Maussion et al. (2014) found high variability of precipitation seasonality along the central and east Himalayas. We could not find such a high variability of precipitation seasonality in the APHRODITE products because of their coarse resolution. Such discrepancy in precipitation seasonality might cause errors in calculated precipitation.

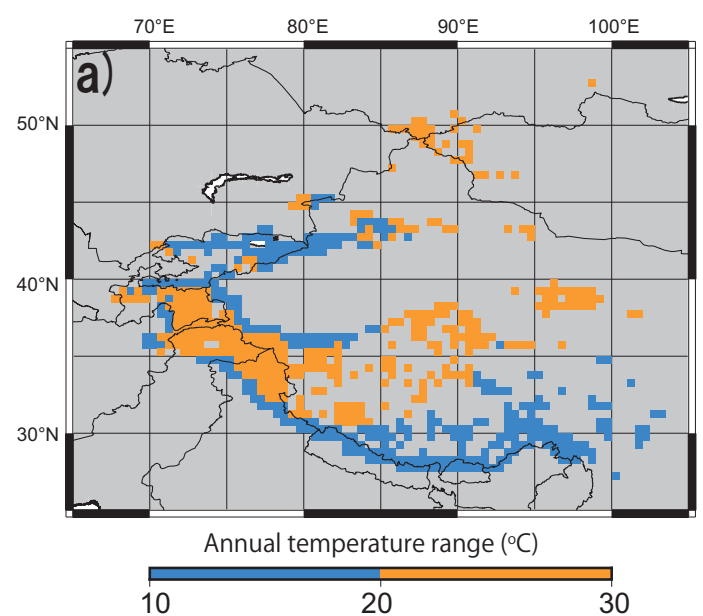

b)

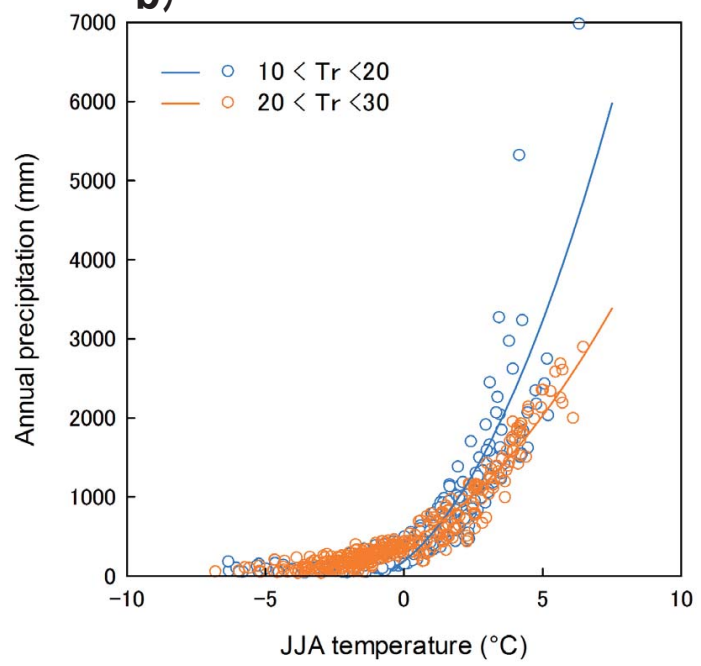

Figure 11. Distribution of annual temperature range (a) and T-P plot of different temperature ranges. Tr indicates annual temperature range (b).

\subsubsection{Annual temperature range}

We classified glaciers in high-mountain Asia by annual temperature range, which is calculated on the basis of monthly temperature (Fig. 11a). Low annual temperature range $\left(10<T_{\mathrm{r}}<20\right)$ area expands to Hengduan Shan, Himalayas, western Kunlun, and Tien Shan. We made a T-P plot for different annual temperature ranges in Fig. 11b, as analysed by Braithwaite (2008). Glaciers with a low annual temperature range have a higher T-P plot gradient, which means that those glaciers have higher sensitivity to climate (temperature and precipitation) changes, which is the same result as with Braithwaite (2008). Glaciers with a high annual temperature range $\left(20<T_{\mathrm{r}}<30\right)$, which have less sensitivity to climate change, are distributed throughout Sayan, Altai, the Tibetan Plateau, Karakoram, Hindu Kush, and Pamir. Those regions - except for Sayan, Altai, and Hindu Kush - corre- 
spond to slight mass gain areas (Gardner et al., 2013). They have less sensitivity to climate change because a high annual temperature range might be one of the reasons for recent glacier mass gain in these regions.

\subsection{Adjustment ratio of precipitation: $A_{\mathrm{p}}$}

Figure 12 shows the distribution of $A_{\mathrm{p}}$ (adjustment ratio of APHRODITE data), calculated on the basis of W-average elevation. Although $\mathrm{W}$-average elevation in most grids is higher than the elevation in the grid average (including glacier-free zones), the eastern Himalayas, the central Himalayas, Pamir, Karakoram, and central Tien Shan have adjustment ratios of less than 1, implying that the APHRODITE precipitation data overestimate the precipitation at the average elevation of glaciers.

We compared the altitudinal distributions of grid numbers for the average elevation of glaciers and the mean altitude of each grid in the Himalayas and the Karakoram (Fig. S10a and b). Both modes of average elevation of glaciers and mean altitude of grids show a similar altitude (5000 and $5500 \mathrm{~m}$ a.s.1., respectively). On the other hand, in the Himalayan region, several researchers reported that maximum precipitation occurs at $3000 \mathrm{~m}$ elevation (Burbank et al., 2003; Putkonen, 2004; Bookhargen and Burbank, 2006), which is lower than the $\mathrm{W}$-average elevation of glaciers (Fig. S10a). Thus, the calculated precipitation at the average elevation of glaciers would be much less than the grid average precipitation $(<0.6)$, which is also affected by larger precipitation at lower elevation because precipitation gauges are usually set at low elevation. Hence, almost all grid cells have less than 0.6 in $A_{\mathrm{p}}$ (Fig. S10c). Fujita and Nuimura (2011) and Fujita and Sakai (2014) also reported that observed precipitation at Tsho Rolpa in the east Nepal Himalayas $\left(27.9^{\circ} \mathrm{N}, 86.5^{\circ} \mathrm{E}\right)$ was less than the APHRODITE precipitation data. In the Karakoram region, most grid cells have $A_{\mathrm{p}}$ close to $1(0.4-1.0)$ in Fig. S10c. The reason is that glaciers in the Karakoram have almost the same altitudinal distribution of $\mathrm{W}$-average glacier elevation and average ground altitude, at which the altitude of peak precipitation (5000-6000 m a.s.l.) corresponded (Wake, 1989; Young and Schmok, 1989; Young and Hewitt, 1990; Hewitt, 2011).

Yatagai et al. (2012) compared APHRODITE with the Global Precipitation Climatology Centre (GPCC) product, which is also compiled gauge precipitation data. Distribution of the difference (APHRODITE-GPCC) (Fig. 9a of Yatagai et al., 2012) indicates that APHRODITE estimates less precipitation than the GPCC product in most areas. APHRODITE data, however, were larger than the GPCC product only around the central Tien Shan and Pamir regions. Thus, those regions have an adjustment ratio of less than 1 .

Three grids have an extremely large $A_{\mathrm{p}}(>10)$, indicated by A-C in Fig. 12. A $\left(48.5-49.0^{\circ} \mathrm{N}, 89.0-89.5^{\circ} \mathrm{E}\right)$ and $\mathrm{C}$ $\left(28.0-28.5^{\circ} \mathrm{N}, 93.0-93.5^{\circ} \mathrm{E}\right)$ having a large $A_{\mathrm{p}}$ can be explained by missed delineation of glacier area. Glaciers in the

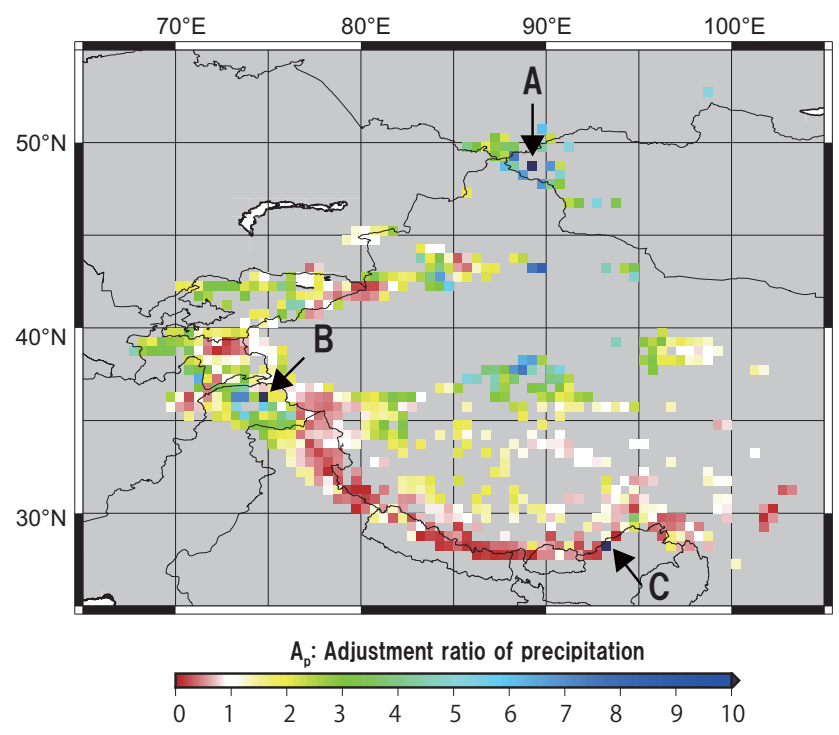

Figure 12. Distribution of the adjustment ratio of $P_{\mathrm{W}}$ to APHRODITE precipitation in each $0.5^{\circ}$ grid. Grids with adjustment ratio between 0.9 and 1.1 are indicated by white. (A), (B), and (C) indicate grid cells with large $A_{\mathrm{p}}(>10)$.

shade at the upper part of the glacier area are excluded in grid $\mathrm{A}$, and some snow patches at the top of the mountain ridges are included in the error in grid C. In grid B (36.0$36.5^{\circ} \mathrm{N}, 74.5-75.0^{\circ} \mathrm{E}$ ), the upper part of the glaciers in the GGI is excluded; furthermore, a high mountain peak is located north of the grid, and glaciers flow down from the peak. In the calculation of $\mathrm{W}$-average elevation, other relatively low-peak mountains are applied for the maximum altitude of ground. Then the $\mathrm{W}$-average elevation is underestimated.

\section{Conclusions}

We calculated precipitation at median elevation by assuming that median elevation coincides with ELA, using a climatic glacier mass balance model by adjusting precipitation data. Three types of average elevations of glaciers are proposed. They are (1) G-average elevation, which includes small glaciers $\left(<1 \mathrm{~km}^{2}\right)$; (2) L-average elevation, which eliminates small glaciers; and (3) W-average elevation, which is calculated to include steep avalanche walls. L-average elevation eliminated local terrain effects, such as drifting snow, which was included in G-average elevation. W-average elevation depends only on climate and excludes the effect of avalanche nourishment.

Precipitation estimated based on G- and L-average elevation has extremely large values in several tens of grids, and those fitted curves of T-P plots have large gradients. In contrast, distribution of precipitation calculated on the basis of $\mathrm{W}$-average elevation reduces the number of extremely large amounts of precipitation, because the $\mathrm{W}$-average glacier el- 
evation depends only on climate and is not affected by avalanche nourishment.

Estimated precipitation at $\mathrm{W}$-average elevations elucidated the T-P conditions of glaciers in high-mountain Asia. Glaciers in high-mountain Asia are located in lowtemperature zones, like glaciers in the Arctic. Furthermore, it was elucidated that glaciers in high relief terrains (such as the central and eastern Himalayas, and the Hengduan Shan, the Karakoram, and the Pamir) tend to have large amounts of avalanche nourishment contribution to the glacier mass by comparing $P_{\mathrm{L}}$ (including avalanche nourishment) and $P_{\mathrm{W}}$ (only direct precipitation).

We differentiated summer-accumulation-type glaciers and winter-accumulation-type glaciers using the $40 \%$ summer precipitation ratio to annual precipitation. Fitted curves of winter-accumulation-type glaciers corresponded well with Ohmura's equation. However, the curves of summeraccumulation-type glaciers have higher gradients, particularly at larger precipitation ranges, which indicate that summer-accumulation-type glaciers have higher sensitivity to climate change. P-T plots classified by high and low annual temperature ranges clarified that glaciers with a high annual temperature range have lower sensitivity to climate change, as indicated by Braithwaite (2008). Furthermore, low sensitivity to climate change because of high annual temperature range might be one of the reasons for the recent slight mass gain in glaciers in Karakoram, Pamir, and the Tibetan Plateau reported by Gardner et al. (2013).

$A_{\mathrm{p}}$ values were much less than 1 in the western, central, and eastern Himalayas, and approximately 1 at Karakoram. The reason for this finding is the altitudinal relation between the average elevation of glaciers and the precipitation gradient.

In future studies, the estimated precipitation in highmountain Asia will possibly reveal the precise sensitivity of glaciers to climate change, and they will provide a proper contribution of glacier run-off in high-mountain Asia.

\section{The Supplement related to this article is available online at doi:10.5194/tc-9-865-2015-supplement.}

Acknowledgements. We thank T. Bolch, R. Braithwaite, and an anonymous reviewer for their valuable comments. This research was supported by the Funding Program for Next Generation World-Leading Researchers (NEXT Program). We express our sincere thanks and appreciation for great support to Y. Hoshina, S. Tsutaki, K. Tsunematu, S. Omiya, S. Okamoto, K. Taniguchi, and P. Tshering.

Edited by: T. Bolch

\section{References}

Adam, J. C., Clark, E. A., Lettenmaier, D. P., and Wood, E. F.: Correction of global precipitation products for orographic effects, J. Climate, 19, 15-38, 2006.

Ageta, Y. and Higuchi, K.: Estimation of mass balance components of summer-accumulation type glacier in the Nepal Himalaya, Geogr. Ann. A, 66, 249-255, 1984.

Aizen, V. B., Aizen, E. M., Joswiak, D. R., Fujita, K., Takeuchi, N., and Nikitin, S. A.: Climatic and atmospheric circulation pattern variability from ice-core isotope/geochemistry records (Altai, Tien Shan and Tibet), Ann. Glaciol., 43, 49-60, 2006a.

Aizen, V. B., Kuzmichenok, V. A., Surazakov, A. B., and Aizen, E. M.: Glacier changes in the central and northern Tien Shan during the last 140 years based on surface and remote-sensing data, Ann. Glaciol., 43, 202-213, 2006b.

Bajracharya, S. R. and Shrestha, B. (Eds.): The status of glaciers in the Hindu Kush-Himalayan region, International Centre for Integrated Mountain Development, Kathmandu, 2011.

Benn, I. D. and Lehmkuhl, F.: Mass balance and equilibrium-line altitudes of glaciers in high-mountain environments, Quatern. Int. 65/66, 15-29, 2000.

Böhner, J.: General climatic controls and topoclimatic variations of Central and High Asia, Boreas, 35, 279-295, 2006.

Bolch, T., Kulkarni, A., Kääb, A., Huggel, C., Paul, F., Cogley, J., Frey, H., Kargel, J., Fujita, K., Scheel, M., Bajracharya, S., and Stoffel, M.: The state and fate of Himalayan Glaciers, Science, 336, 310-314, doi:10.1126/science.1215828, 2012.

Bookhagen, B. and Burbank, D. W.: Topography, relief, and TRMM-derived rainfall variations along the Himalaya, Geophys. Res. Lett., 33, L08405, doi:10.1029/2006GL026037, 2006.

Bookhagen, B. and Burbank, D.: Toward a complete Himalayan hydrological budget: spatiotemporal distribution of snowmelt and rainfall and their impact on river discharge, J. Geophys. Res., 115, F03019, doi:10.1029/2009JF001426, 2010.

Braithwaite, R. J.: Temperature and precipitation climate at the equilibrium-line altitude of glaciers expressed by the degree-day factor for melting snow, J. Glaciol., 54, 437-444, 2008.

Braithwaite, R. J. and Raper, S. C. B.: Glaciers and their contribution to sea level change, Phys. Chem. Earth, 27, 1445-1454, 2002.

Braithwaite, R. J. and Raper, S. C. B.: Estimating equilibrium-line altitude (ELA) from glacier inventory data, Ann. Glaciol., 53, 127-132, 2009.

Braithwaite, R. J. and Zhang, Y.: Modelling changes in glacier mass balance that may occur as a result of climate changes, Geogr. Ann. A, 81, 489-496, 1999.

Braithwaite, R. J., Raper, S. C. B., and Chutko, K.: Accumulation at the equilibrium-line altitude of glaciers inferred from a degreeday model and tested against field observations, Ann. Glaciol., 43, 329-334, 2006.

Burbank, D. W., Blythe, A. E., Putkonen, J., Pratt-Sitaula, B., Gabet, E., Oskin, M., Barros, A., and Ojha, T. P.: Decoupling of erosion and precipitation in the Himalayas, Nature, 426, 652-655, doi:10.1038/nature02187, 2003. 
Carrivick, J. L. and Brewer, T. R.: Improving local estimations and regional trends of glacier equilibrium line altitudes, Geogr. Ann. A, 86, 67-79, 2004.

Chen, M. P., Xie, P., Janowiak, J. E., and Arkin, P. A.: Global land precipitation: A 50-yr monthly analysis based on gauge observations, J. Hydrometeorol., 3, 249-266, 2002.

Dahl, S. O. and Nesje, A.: Paleoclimatic implications based on equilibrium-line altitude depressions of reconstructed Younger Dryas and Holocene cirque glaciers in inner Nordfjord, western Norway, Palaeogeogr. Palaeocl., 94, 87-97, 1992.

Daly, C., Neilson, R. P., and Phillips, D. L.: A statisticaltopographic model for mapping climatological precipitation over mountainous terrain, J. Appl. Meteorol., 33, 140-158, 1994.

Dee, D. P., Uppala, S. M., Simmons, A. J., Berrisford, P., Poli, P., Kobayashi, S., Andrae, U., Balmaseda, M. A., Balsamo, G., Bauer, P., Bechtold, P., Beljaars, A. C. M., van de Berg, L., Bidlot, J., Bormann, N., Delsol, C., Dragani, R., Fuentes, M., Geer, A. J., Haimberger, L., Healy, S. B., Hersbach, H., Hólm, E. V., Isaksen, L., Kållberg, P., Köhler, M., Matricardi, M., McNally, A. P., Monge-Sanz, B. M., Morcrette, J.-J., Park, B.-K., Peubey, C., de Rosnay, P., Tavolato, C., Thépaut, J.-N., and Vitart, F.: The ERA-Interim reanalysis: configuration and performance of the data assimilation system, Q. J. Roy. Meteorol. Soc., 137, 553597, doi:10.1002/qj.828, 2011.

Dyurgerov, M. B.: Glacier mass balance and regime: Data of measurements and analysis, Occasional Paper 55, Institute of Arctic and Alpine Research, University of Colorado, Boulder, CO, 2002.

Engelhardt, M., Schuler, T. V., and Andreassen, L. M.: Evaluation of gridded precipitation for Norway using glacier mass-balance measurements, Geogr. Ann. A, 94, 501-509, doi:10.1111/j.14680459.2012.00473.x, 2012.

Fujita, K.: Effect of precipitation seasonality on climatic sensitivity of glacier mass balance, Earth Planet. Sc. Lett., 276, 14-19, doi:10.1016/j.epsl.2008.08.028, 2008a.

Fujita, K.: Influence of precipitation seasonality on glacier mass balance and its sensitivity to climate change, Ann. Glaciol., 48, 88-92, doi:10.3189/172756408784700824, 2008b.

Fujita, K. and Ageta, Y.: Effect of summer accumulation on glacier mass balance on the Tibetan Plateau revealed by mass-balance model, J. Glaciol., 46, 244-252, 2000.

Fujita, K. and Nuimura, T.: Spatially heterogeneous wastage of Himalayan glaciers, P. Natl. Acad. Sci. USA, 108, 14011-14014, doi:10.1073/pnas.1106242108, 2011.

Fujita, K. and Sakai, A.: Modelling runoff from a Himalayan debris-covered glacier, Hydrol. Earth Syst. Sci., 18, 2679-2694, doi:10.5194/hess-18-2679-2014, 2014.

Fujita, K., Ohta, T., and Ageta, Y.: Characteristics and climatic sensitivities of runoff from a cold-type glacier on the Tibetan Plateau, Hydrol. Process., 21, 2882-2891, doi:10.1002/hyp.6505, 2007.

Fujita, K., Takeuchi, N., Nikitin, S. A., Surazakov, A. B., Okamoto, S., Aizen, V. B., and Kubota, J.: Favorable climatic regime for maintaining the present-day geometry of the Gregoriev Glacier, Inner Tien Shan, The Cryosphere, 5, 539-549, doi:10.5194/tc-5539-2011, 2011.
Gardelle, J., Berthier, E., Arnaud, Y., and Kääb, A.: Region-wide glacier mass balances over the Pamir-Karakoram-Himalaya during 1999-2011, The Cryosphere, 7, 1263-1286, doi:10.5194/tc7-1263-2013, 2013.

Gardner, A. S., Moholdt, G., Cogley, J. G., Wouters, B., Arendt, A. A., Wahr, J., Berthier, E., Hock, R., Pfeffer, W. T., Kaser, G., Ligtenberg, S. R. M., Bolch, T., Sharp, M. J., Hagen, J. O., van den Broeke, M. R., and Paul, F.: A Reconciled Estimate of Glacier Contributions to Sea Level Rise: 2003 to 2009, Science, 340, 852-857, doi:10.1126/science.1234532, 2013.

Harper, J. T. and Humphrey, N.: High Altitude Himalayan Climate Inferred from Glacial Ice Flux, Geophys. Res. Lett., 30, 1764, doi:10.1029/2003GL017329, 2003.

Hewitt, K.: Glacier change, concentration, and elevation effects in the Karakoram Himalaya, Upper Indus Basin, Mt. Res. Dev., 31, 188-200, 2011.

Hewitt, K.: Glaciers of the Karakoram Himalaya, Springer, Dordrecht, Heidelberg, New York, London, 363 pp., 2014.

Huffman, G. J., Adler, R. F., Arkin, P., Chang, A., Ferraro, R., Gruber, A., Janowiak, J., and McNab, A.: The Global Precipitation Climatology Project (GPCP) combined precipitation dataset, B. Am. Meteorol. Soc., 78, 5-20, 1997.

Immerzeel, W. W., Ludovicus, P. H. B., and Bierkens, M. F. P.: Climate Change Will Affect the Asian Water Towers, Science, 328, 1382-1385, doi:10.1126/science.1183188, 2010.

Immerzeel, W. W., Pellicciotti, F., and Shrestha, A. B.: Glaciers as a Proxy to Quantify the Spatial Distribution of Precipitation in the Hunza Basin, Mt. Res. Dev., 32, 30-38, 2012.

Immerzeel, W. W., Pellicciotti, F., and Bierkens, M. F. P.: Rising river flows throughout the twenty-first century in two Himalayan glacierized watersheds, Nat. Geosci., 6, 742-745, doi:10.1038/NGEO1896, 2013.

Jaedicke, C. and Gauer, P.: The influence of drifting snow on the location of glaciers on western Spitsbergen, Svalbard, Ann. Glaciol., 42, 237-242, 2005.

Kääb, A., Berthier, E., Nuth, C., Gardelle, J., and Arnaud, Y.: Contrasting patterns of early twenty-first-century glacier mass change in the Himalayas, Nature,488, 495-498, doi:10.1038/nature11324, 2012.

Kääb, A., Treichler, D., Nuth, C., and Berthier, E.: Brief Communication: Contending estimates of 2003-2008 glacier mass balance over the Pamir-Karakoram-Himalaya, The Cryosphere, 9, $557-$ 564, doi:10.5194/tc-9-557-2015, 2015.

Kalnay, E., Kanamitsu, M., Kistler, R., Collins, W., Deaven, D., Gandin, L., Iredell, M., Saha, S., White, G., Woollen, J., Zhu, Y., Chelliah, M., Ebisuzaki, W., Higgins, W., Janowiak, J., Mo, K. C., Ropelewski, C., Wang, J., Leetmaa, A., Reynolds, R., Jenne, R., and Joseph, D.: The NCEP/NCAR 40-year reanalysis project, B. Am. Meteorol. Soc., 77, 437-471, 1996.

Kaser, G., Großhauser, M., and Marzeion, B.: Contribution potential of glaciers to water availability in different climate regimes, $\mathrm{P}$. Natl. Acad. Sci. USA, 107, 20223-20227, 2010.

Kondo, J. and Xu, J.: Seasonal variations in the heat and water balances for nonvegetated surfaces, J. Appl. Meteorol., 36, 16761695, 1997.

Maussion, F., Scherer, D. Mölg, T. Collier, E. Curio, J., and Finkelnburg, R.: Precipitation seasonality and variability over the Tibetan Plateau as resolved by the High Asia Reanalysis, J. Climate, 27, 1910-1927, doi:10.1175/JCLI-D-13-00282.1, 2014. 
Narama, C., Kääb, A., Duishonakunov, M., and Abdrakhmatov, K.: Spatial variability of recent glacier area changes in the Tien Shan Mountains, Central Asia, using Corona (1970), Landsat (2000), and ALOS (2007) satellite data, Global Planet. Change, 71, 4254, 2010.

Neckel, N., Kropáček, J., Bolch, T., and Hochschild, V.: Glacier mass changes on the Tibetan Plateau 2003-2009 derived from ICESat laser altimetry measurements, Environ. Res. Lett., 9, 14009, doi:10.1088/1748-9326/9/1/014009, 2014.

Nesje, A. and Dahl, S. O.: Glaciers and environmental change, Arnold, London, 2000.

New, M., Hulme, M., and Jones, P.: Representing twentieth century space-time climate variability. I. Development of a 1961-1990 mean monthly terrestrial climatology, J. Climate, 12, 829-856, 1999.

New, M., Hulme, M., and Jones, P.: Representing twentieth-century space-time climate variability, Part II: Development of 1961-90 monthly grids of terrestrial surface climate, J. Climate, 13, 22172238, 2000.

Nuimura, T., Sakai, A., Taniguchi, K., Nagai, H., Lamsal, D., Tsutaki, S., Kozawa, A., Hoshina, Y., Takenaka, S., Omiya, S., Tsunematsu, K., Tshering, P., and Fujita, K.: The GAMDAM Glacier Inventory: a quality controlled inventory of Asian glaciers, The Cryosphere, 9, 849-864, doi:10.5194/tc-9-8492015, 2015.

Oerlemans, J. and Fortuin, J. P. F.: Sensitivity of glaciers and small ice caps to greenhouse warming, Science, 258, 115-117, 1992.

Ohmura, A., Kasser, P., and Funk, M.: Climate at the equilibrium line altitude, J. Glaciol., 38, 397-411, 1992.

Paul, F., Kääb, A., Maisch, M., Kellenberger, T., and Haeberli, W.: The new remote-sensing-derived Swiss glacier inventory: I. Methods, Ann. Glaciol., 34, 355-361, 2002.

Paul, F., Barry, R. G., Cogley, J. G., Frey, H., Haeberli, W., Ohmura, A., Ommanney, C. S. L., Raup, B., Rivera, A., and Zemp, M.: Recommendations for the compilation of glacier inventory data from digital sources, Ann. Glaciol., 50, 119-126, 2009.

Pfeffer, W. T., Arendt, A. A., Bliss, A., Bolch, T., Cogley, J. G., Gardner, A. S., Hagen, J. O., Hock, R., Kaser, G., Kienholz, C., Miles, E. S., Moholdt, G., Mölg, N., Paul, F., Radić, V., Rastner, P., Raup, B. H., Rich, J., and Sharp, M. J.: The Randolph consortium: The Randolph Glacier Inventory: a globally complete inventory of glaciers, J. Glaciol., 60, 537-552, 2014.

Putkonen, J. K.: Continuous snow and rain data at 500 to $4400 \mathrm{~m}$ altitude near Annapurna, Nepal, 1991-2001, Arct. Antarct. Alp. Res., 36, 244-248, doi:10.1657/1523-0430(2004)036, 2004.

Racoviteanu, A. E., Arnaud, Y., Williams, M. W., and Ordonez, J.: Decadal changes in glacier parameters in the Cordillera Blanca, Peru, derived from remote sensing, J. Glaciol., 54, 499-510, 2008.

Rasmussen, L. A.: Meteorological controls on glacier mass balance in High Asia, Ann. Glaciol., 54, 352-359, doi:10.3189/2013AoG63A353, 2013.

Rastner, P., Bolch, T., Mölg, N., Machguth, H., Bris, R. L., and Paul, F.: The first complete inventory of the local glaciers and ice caps on Greenland, The Cryosphere, 6, 1483-1495, doi:10.5194/tc-61483-2012, 2012.

Rupper, S. and Roe, G.: Glacier changes and regional climate: a mass and energy balance approach, J. Climate, 21, 5384-5401, doi:10.1175/2008JCLI2219.1, 2008.
Sakai A., Matsuda, Y., Fujita, K., Matoba, S., Uetake, J., Satow, K., Duan, K., Pu, J., Nakawo, M., and Yao, T.: Meteorological observation at July 1st Glacier in northwest China from 2002 to 2005, Bull. Glaciol. Res., 23, 23-31, 2006.

Sato, T., Tsujimura, M., Yamanaka, T., Iwasaki, H., Sugimoto, A., Sugita, M., Kimura, F., Davaa, G., and Oyunbaatar, D.: Water sources in semiarid northeast Asia as revealed by field observations and isotope transport model. J. Geophys. Res., 112, D17112, doi:10.1029/2006JD008321, 2007.

Scherler, D., Bookhagen, B., and Strecker, M. R.: Hillslope glacier coupling: The interplay of topography and glacial dynamics in High Asia, J. Geophys. Res., 116, F02019, doi:10.1029/2010JF001751, 2011.

Shi, Y. (Eds.): Concise Glacier Inventory of China, Shanghai Popular Science Press, Shanghai, China, 2008.

Sorg, A., Bolch, T., Stoffel, M., Solomina, O., and Beniston, M.: Climate change impacts on glaciers and runoff in Tien Shan (Central Asia), Nat. Clim. Change, 2, 725-731, doi:10.1038/NCLIMATE1592, 2012.

Surazakov, A. B., Aizen, V. B., Aizen, E. M., and Nikitin, S. A. Glacier changes in the Siberian Altai Mountains, Ob river basin, (1952-2006) estimated with high resolution imagery, Environ. Res. Lett., 2, 045017, doi:10.1088/1748-9326/2/4/045017, 2007.

Torsnes, I., Rye, N., and Nesje, A.: Modern and Little Ice Age equilibrium-line altitudes on outlet valley glaciers from Jostedalsbreen, Norway: an evaluation of different approaches to their calculation, Arct. Alp. Res., 25, 106-116, 1993.

Ueno, K., Endoh, N., Ohata, T., Yabuki, H., Koike, T., Koike, M., Ohta, T., and Zhang, Y.: Characteristics of precipitation distribution in Tanggula, Monsoon, 1993, Bull. Glacier Res., 12, 39-47, 1994.

Wake, C. P.: Glaciochemical investigations as a tool to determine the spatial variation of snow accumulation in the Central Karakoram, Northern Pakistan, Ann. Glaciol., 13, 279-284, 1989.

Yang, W., Yao, T., Guo, X., Zhu, M., Li, S., and Kattel, D. B.: Mass balance of a maritime glacier on the southeast Tibetan Plateau and its climatic sensitivity, J. Geophys. Res., 118, 9579-9594, doi:10.1002/jgrd.50760, 2013.

Yao, T., Thompson, L., Yang, W., Yu, W., Gao, Y., Guo, X., Yang, X., Duan, K., Zhao, H., Xu, B., Pu, J., Lu, A., Xiang, Y., Kattel, D. B., and Joswiak, D.: Different glacier status with atmospheric circulations in Tibetan Plateau and surroundings, Nat. Clim. Change, 2, 663-667, doi:10.1038/nclimate1580, 2012.

Yatagai, A., Arakawa, O., Kamiguchi, K., Kawamoto, H., Nodzu, M. I., and Hamada, A.: A 44-year daily gridded precipitation dataset for Asia based on a dense network of rain gauges, Scient. Onl. Lett. Atmos., 5, 137-140, doi:10.2151/sola.2009-035, 2009.

Yatagai, A., Kamiguchi, K., Arakawa, O., Hamada, A., Yasutomi, N., and Kitoh, A.: APHRODITE: Constructing a Long-term Daily Gridded Precipitation Dataset for Asia based on a Dense Network of Rain Gauges, B. Am. Meteorol. Soc., 93, 1401-1415, doi:10.1175/BAMS-D-11-00122.1, 2012.

Yoshimura, K., Oki, T., Ohte, N., and Kanae, S.: Colored Moisture Analysis Estimates of Variations in 1998 Asian Monsoon Water Sources, J. Meteorol. Soc. Jpn., 82, 1315-1329, 2004.

Young, G. J. and Hewitt, K.: Hydrology research in the upper Indus basin, Karakoram Himalaya, Pakistan, IAHS Publ., 190, 139152, 1990. 
Young, G. J. and Schmok, J. P.: Ice loss in the ablation area of a Himalayan glacier: Studies on Miar Glacier, Karakorum Mountains, Pakistan, Ann. Glaciol., 13, 289-293, 1989.
Zech, R., Abramowski, U., Glaser, B., Sosin, P., Kubik, P. W., and Zech, W.: Late Quaternary glacial and climate history of the Pamir Mountains derived from cosmogenic ${ }^{10} \mathrm{Be}$ exposure ages, Quaternary Res., 64, 212-220, 2005. 